\title{
Non-Verbal Mother-Child Communication in conditions of Maternal HIV in an Experimental Environment ${ }^{1}$
}

\author{
Simone de Sousa Paiva ${ }^{2}$ \\ Marli Teresinha Gimeniz Galvão ${ }^{3}$ \\ Lorita Marlena Freitag Pagliuca ${ }^{4}$ \\ Paulo César de Almeida ${ }^{5}$
}

\begin{abstract}
Non-verbal communication is predominant in the mother-child relation. This study aimed to analyze non-verbal mother-child communication in conditions of maternal HIV. In an experimental environment, five HIV-positive mothers were evaluated during care delivery to their babies of up to six months old. Recordings of the care were analyzed by experts, observing aspects of non-verbal communication, such as: paralanguage, kinesics, distance, visual contact, tone of voice, maternal and infant tactile behavior. In total, 344 scenes were obtained. After statistical analysis, these permitted inferring that mothers use non-verbal communication to demonstrate their close attachment to their children and to perceive possible abnormalities. It is suggested that the mother's infection can be a determining factor for the formation of mothers' strong attachment to their children after birth.

Descriptors: Acquired Immunodeficiency Syndrome; Mother-Child Relations; Nonverbal Communication; HIV.
\end{abstract}

\footnotetext{
${ }^{1}$ Article extracted from Master's Dissertation "Análise da comunicação não verbal da mãe-filho na vigência do HIV materno em ambiente experimental" presented to Graduate Program in nursing, Universidade Federal do Ceará, Brazil. Funded by Fundação Cearense de Apoio ao Desenvolvimento Científico e Tecnológico (FUNCAP).

${ }^{2}$ RN, M.Sc., e-mail: simonecvc@yahoo.com.br.

${ }^{3}$ Ph.D. in Nursing, Faculty, Nursing Department, Universidade Federal do Ceará, Brazil, e-mail marligalvao@gmail.com.

${ }^{4}$ Ph.D. in Nursing, Full Professor, Nursing Department, Universidade Federal do Ceará, Brazil, e-mail: pagliuca@ufc.br.

${ }^{5}$ Statistician, Ph.D., Adjunct Professor, Universidade Estadual do Ceará, Brazil, e-mail: pcalmeida49@zipmail.com.
}

Corresponding Author:

Marli Teresinha Gimeniz Galvão

Departamento de Enfermagem. Faculdade de Farmácia

Odontologia e Enfermagem. Universidade Federal do Ceará.

Rua Alexandre Baraúna, 1115. Bairro Rodolfo Teófilo

CEP: 60430-160 Fortaleza, CE, Brasil

E-mail: marligalvao@gmail.com 


\title{
Comunicação não-verbal mãe/filho na vigência do HIV materno em ambiente experimental
}

A comunicação não-verbal é predominante na relação entre mãe/filho. Objetivou-se verificar a comunicação não-verbal mãe/filho na vigência do HIV materno. Em ambiente experimental, foram avaliadas cinco mães HIV+, no exercício de cuidados com seus filhos de até seis meses de vida. Filmagens dos cuidados foram analisadas por peritos, sendo observados os aspectos da comunicação não-verbal, como: a paralinguagem, cinestésica, distância, contato visual, tom de voz, comportamento tátil materno e infantil. Obteve-se 344 cenas que, após análise estatística, possibilitou inferir que a comunicação não-verbal é utilizada pela mãe para demonstrar seu íntimo apego aos filhos e para perceber possíveis anormalidades. Sugere-se que a infecção materna pode ser fator determinante para a formação de forte apego materno ao seu bebê após o nascimento.

Descritores: Síndrome de Imunodeficiência Adquirida; Relações Mãe-Filho; Comunicação não Verbal; HIV.

\section{Comunicación no verbal madre/hijo em la existencia del HIV materna en ambiente experimental}

\begin{abstract}
La comunicación no verbal es predominante en la relación entre madre/hijo. Se tuvo por objetivo verificar la comunicación no verbal madre/hijo en la existencia del HIV materno. En ambiente experimental, fueron evaluadas cinco madres HIV+, que cuidaban de sus hijos de hasta seis meses de vida. Las filmaciones de los cuidados fueron analizadas por peritos, siendo observados los aspectos de la comunicación no verbal, como: paralenguaje, cinestésica, proximidad, contacto visual, tono de voz y comportamiento táctil materno e infantil. Se obtuvo 344 escenas que, después de un análisis estadístico, posibilitó inferir que la comunicación no verbal es utilizada por la madre para demonstrar su apego íntimo a los hijos y para percibir posibles anormalidades. Se sugiere que la infección materna puede ser un factor determinante para la formación del fuerte apego de la madre por su bebé después el nacimiento.
\end{abstract}

Descriptores: Síndrome de Inmunodeficiencia Adquirida; Relaciones Madre-Hijo; Comunicación no Verbal; VIH

\section{Introduction}

Both pregnancy and motherhood involve important changes in women's lives, which demand successive and long-term adaptations ${ }^{(1)}$.

Like any developmental crisis, pregnancy unbalances a person's lifecycle (2). This unbalance can be greater or smaller depending on how the crisis is experienced. For women with HIV/AIDS, the particularities of seropositive status are added to the unbalance of bearing a child(3). Thus, because this crisis period is more intensive for HIV-positive women than it usually is for pregnant women, the relation with the child can be impaired in this process. When she discovers that she has a disease that can jeopardize the baby, this can arouse feelings of anxiety and guild in the future mother ${ }^{(4)}$, as she hopes the child will be born healthy.

Besides suffering the social stigma of a discriminated and incurable disease, these women need to follow a series of recommendations so as not to contaminate their children, measures that are not socially encouraged and often lie far beyond their financial possibilities, such as the adoption of artificial feeding for their children.

Feelings deriving from the diagnosis of HIV-positive status, recommendations to avoid contaminating the child and restrictions on the mother's care for her child can influence the relation between HIV-positive mothers and their children. 
The mother-child relationship is based on communication, mainly the non-verbal kind. Communication is essential for the relationship between mothers and children and nurses taking care of these binomials should pay particular attention to this aspect. The mother's voice and the way she caresses her baby indicate her willingness to take care of her child(5). Therefore, communicative manifestations between mother and baby should be observed and assessed, mainly when non-verbal language is used, as that is the predominant communication form in the binomial at the start of the child's life, with a view to detecting any route that moves towards the opposite sense of a healthy relationship between mother and child. In this perspective, this research aimed to verify non-verbal communication (NVC) between mother and child in cases of maternal HIV in an experimental environment.

\section{Methodological Aspects}

Studies in experimental environments are not very common to assess maternal care. Hence, a descriptive research was carried out at the Health Communication Laboratory (LabCom_Saúde) in Fortaleza, Ceará, Brazil.

The study was carried out in the second semester of 2007 and involved five binomials (mother/child) in which the mother's HIV status was positive and the children, exposed to the virus at birth, where six months of age or younger. The following inclusion criteria were adopted: HIV-positive mothers, living in Fortaleza and agreeing to participate in the research. Children younger than six months were chosen intentionally because this in an important phase for mother-child bonding and precedes it. Hence, it is a favorable period to assess NVC.

For data collection, semistructured interviews were used to obtain identification and socioeconomic data, obstetrical information and data about the diagnosis. Film recordings were used to capture and register information. In the experimental environment, two cameras were places in different strategic sites, so that the entire environment could be filmed, capturing the scenes without interfering in care.

To develop the research, a scenario similar to the home environment was set $u$ at the laboratory, allowing the mother to deliver five types of care to her child, that is: bathing, changing clothes, offering the bottle (feeding), a playful moment (playing) and putting the baby to sleep (lulling/rocking). These situations occurred because they are care circumstances the mothers perform with their children on a daily basis. All communication actions related to these care types were added up and later evaluated.

In an attached room, a computer was connected with the cameras and stored the data. The researchers stayed in that environment, controlling the equipment and observing what was happening with the binomial during care without interfering in the recording environment.

To analyze data from the recordings, two experts (judges) participated, whose criteria for participation were: nurses with at least a master's degree who had developed research and were researching on non-verbal communication.

Scenes for each care type were assessed from the start until the end of interactions. No period was determined for the care, because each mother delivers care in her own way and at her own pace. To analyze the scenes for each care type, the video (recording) was paused every thirty seconds and individually assessed by the judges who marked, using a check list observation script, the elements of $\mathrm{NVC}^{(7-8)}$ that emerged in the recording intervals. Hence, each completed script corresponded to an interaction. The judges analyzed the following variables:

- paralanguage - produced sounds that were not understandable in the language used;

- kinesics - postures and positions maintained during the interaction;

- distance - refers to the space maintained between the interlocutors during the interaction;

- visual contact - more specialized sense of human beings, who receives information effectively and immediately. Looking reflects feelings and intentions at the same time;

- tone of voice - the tone of voice during a conversation, whether verbal or not. This can reflect feelings from the interlocutor who issues the message;

- the child's crying or moaning - belongs to paralanguage. In this research, it was considered another variable because it indicates the baby's feelings of discomfort, pain or dissatisfaction during communication;

- touch - refers to the characteristics involved in the act of touching the other. In this research, the type of maternal touch was considered, as well as the baby's behaviors that could suggest the desire to touch the mother or not. It is hard to discover whether touching provoked by a child of less than six months old was 
intentional or not. In this variable, maternal smiling was also observed, demonstrating satisfaction or pleasure while touching.

Moreover, specifically to assess distances, widely disseminated measures were adopted ${ }^{(8)}$, which were: 1. intimate distance - zero to $50 \mathrm{~cm}$ and 2 . personal distance - 50 to $120 \mathrm{~cm}$.

The experts' records were grouped per binomial and analyzed, using proportion analyses and associations ( $z$ and $\mathrm{X}^{2}$ tests), setting the significance level at $1 \%$.

In compliance with ethical requirements, the study received approval from the Research Ethics Committee at Ceará Federal University, Protocol No. 151/07. The mothers were invited to participate in the research during health follow-up at the HIV/AIDS referral service in Fortaleza, Ceará. As required for research involving human beings, mothers received the necessary information about the study objectives. All participants signed the free and informed consent term. With a view to preserving the participants' anonymity, each binomial received a number according to the order of participation (1 to 5 ).

\section{Results}

Next, the findings are presented that characterize the five mother/child binomials. As for the mothers, ages ranged from 18 to 34 years. They informed they had received the diagnosis between 1 and 4 years earlier and had a stable relation with their partners, only one of whom was HIV-positive. Per capita income ranged from 53 to 175 reais, and one mother mentioned no revenues (minimum wage at the time of study was $\mathrm{R} \$ 350,00$ - three hundred and fifty reais). According to most mothers, their children were wanted. The mothers used $\mathrm{AZT}^{\circledR}$ (Zidovudina) to reduce vertical HIV transmission. As for the babies, they were between 39 and 175 days old. All of them were born through c-section and within normality standards.

With regard to the aspects of NVC, in this research, each expert analyzed 172 interactions for the five binomials, totaling 344 interactions: 82 in binomial 1; 58 in binomial 2; 72 in binomial 3; 58 in binomial 4 and 74 in binomial 5 .

Table 1 displays the NVC elements observed in each mother/child binomial.

Table 1 - Association between the variables of each mother/child binomial and non-verbal communication factors for the set of five procedures. Fortaleza, 2007

\begin{tabular}{|c|c|c|c|c|c|c|c|}
\hline \multirow{3}{*}{ Non-verbal communication } & \multicolumn{7}{|c|}{ Binomial } \\
\hline & 1 & 2 & 3 & 4 & 5 & 2 & \\
\hline & $\mathrm{N}^{\circ}(\%)$ & $\mathbf{N}^{\circ}(\%)$ & $\mathbf{N}^{\circ}(\%)$ & $\mathbf{N}^{\circ}(\%)$ & $\mathrm{N}^{\circ}(\%)$ & $x^{2}$ & $p$ \\
\hline Paralanguage & & & & & & 122.75 & 0.0001 \\
\hline Child produces sound & $28(34.2)$ & $4(6.9)$ & $11(15.3)$ & $10(17.2)$ & - & & \\
\hline Mother produces sound & $1(1.2)$ & $25(43.1)$ & $18(25)$ & $28(48.3)$ & $47(63.5)$ & & \\
\hline Both produce sound & $6(7.3)$ & $2(3.5)$ & $20(27.8)$ & $5(8.6)$ & $3(4.1)$ & & \\
\hline Absence $^{*}$ & $47(57.3)$ & $27(46.5)$ & $23(31.9)$ & $15(25.9)$ & $24(32.4)$ & & \\
\hline Total & $82(100)$ & $58(100)$ & $72(100)$ & $58(100)$ & $74(100)$ & & \\
\hline Kinesics** & & & & & & 44.89 & 0.0001 \\
\hline Lateral & $22(26.8)$ & $15(25.9)$ & $31(43)$ & $6(10.3)$ & $3(4.1)$ & & \\
\hline Front & $55(67.1)$ & $42(72.4)$ & $38(52.8)$ & $52(89.7)$ & $65(87.8)$ & & \\
\hline Back & $5(6.1)$ & $1(1.7)$ & $3(4.2)$ & - & $6(8.1)$ & & \\
\hline Total & $82(100)$ & $58(100)$ & $72(100)$ & $58(100)$ & $74(100)$ & & \\
\hline Distance & & & & & & 18.63 & 0.0001 \\
\hline Intimate & $66(80.5)$ & $50(86.2)$ & $53(73.6)$ & $52(89.7)$ & $72(97.3)$ & & \\
\hline Personal & $16(19.5)$ & $8(13.8)$ & $19(26.4)$ & $6(10.3)$ & $2(2.7)$ & & \\
\hline Total & $82(100)$ & $58(100)$ & $72(100)$ & $58(100)$ & $74(100)$ & & \\
\hline Visual contact & & & & & & 53.74 & 0.0001 \\
\hline Child looks at mother & $4(4.9)$ & $2(3.4)$ & $4(5.6)$ & - & $1(1.4)$ & & \\
\hline Mother looks at child & $64(78.1)$ & $33(57)$ & $44(61.1)$ & $28(48.3)$ & $33(44.6)$ & & \\
\hline Eye-to-eye contact & $7(8.5)$ & $21(36.2)$ & 23 (31.9) & $30(51.7)$ & $40(54.0)$ & & \\
\hline No visual contact & $7(8.5)$ & $2(3.4)$ & $1(1.4)$ & - & - & & \\
\hline Total & $82(100)$ & $58(100)$ & $72(100)$ & $58(100)$ & $74(100)$ & & \\
\hline
\end{tabular}


Table 1 - Continuation

\begin{tabular}{|c|c|c|c|c|c|c|c|}
\hline \multirow{3}{*}{ Non-verbal communication } & \multicolumn{7}{|c|}{ Binomial } \\
\hline & 1 & 2 & 3 & 4 & 5 & \multirow{2}{*}{$x^{2}$} & \multirow{2}{*}{$\mathbf{p}$} \\
\hline & $\mathrm{N}^{\circ}(\%)$ & $\mathbf{N}^{\circ}(\%)$ & $\mathrm{N}^{\circ}(\%)$ & $\mathbf{N}^{\circ}(\%)$ & $\mathrm{N}^{\circ}(\%)$ & & \\
\hline Maternal tone of voice & & & & & & 301.50 & 0.0001 \\
\hline Low & $2(2.4)$ & $23(39.7)$ & $30(41.7)$ & $8(13.8)$ & $4(5.4)$ & & \\
\hline Whispering & $5(6.1)$ & $2(3.4)$ & $3(4.2)$ & $27(46.6)$ & $45(60.8)$ & & \\
\hline High/normal & - & $19(32.8)$ & $33(45.8)$ & - & - & & \\
\hline Silence & $75(91.5)$ & $14(24.1)$ & $6(8.3)$ & $23(39.6)$ & $25(33.8)$ & & \\
\hline Total & $82(100)$ & $58(100)$ & $72(100)$ & $58(100)$ & $74(100)$ & & \\
\hline Crying/moaning (produced by baby) & & & & & & 13.89 & 0.008 \\
\hline Yes & $10(12.2)$ & - & $10(13.9)$ & $13(22.4)$ & $9(12.2)$ & & \\
\hline No & $72(87.8)$ & $58(100)$ & $62(86.1)$ & $45(77.6)$ & $65(87.8)$ & & \\
\hline Total & $82(100)$ & $58(100)$ & $72(100)$ & $58(100)$ & $74(100)$ & & \\
\hline Child behavior & & & & & & 121.27 & 0.0001 \\
\hline Turns towards mother & $10(12.2)$ & $29(50)$ & $21(29.2)$ & $39(67.2)$ & $60(81)$ & & \\
\hline Turns to opposite side & $30(36.6)$ & $20(34.5)$ & $17(23.6)$ & $17(29.3)$ & $13(17.6)$ & & \\
\hline Absence $^{*}$ & $42(51.2)$ & $9(15.5)$ & $34(47.2)$ & $2(3.5)$ & $1(1.4)$ & & \\
\hline Total & $82(100)$ & $58(100)$ & $72(100)$ & $58(100)$ & $74(100)$ & & \\
\hline Mother's tactile behavior & & & & & & 42.00 & 0.0001 \\
\hline Localized touching & $47(57.3)$ & $35(60.4)$ & $49(68)$ & $44(75.9)$ & $36(48.7)$ & & \\
\hline Strongly holding & $26(31.7)$ & $18(31)$ & $12(16.7)$ & $8(13.8)$ & $27(36.5)$ & & \\
\hline Caressing & $9(11)$ & $3(5.2)$ & $9(12.5)$ & $4(6.9)$ & $1(1.3)$ & & \\
\hline Smiling & - & $2(3.4)$ & $2(2.8)$ & $1(1.7)$ & $10(13.5)$ & & \\
\hline
\end{tabular}

*Refers to non-occurrence of the situation. **Refers to the mother's position.

As evidenced in Table 1, statistically significant associations were found between all categories of manifestations in the non-verbal communication process and the binomials. Next, each of the NVC observations is presented.

Paralanguage: as for sound production, the child in binomial 1 presented more sounds (34.2\%), while the mother produced a small percentage (1.2\%). The greatest presence of sound was found in binomials 4 $(48.3 \%)$ and $5(63.5 \%)$. In binomial 3, mother and child produced more sounds $(27.8 \%)$ than in the other binomials. In binomials 1 and 2, on the other hand, absence of paralanguage was evidenced, with 57.3 and $46.5 \%$, respectively.

Kinesics: a relatively high percentage of lateral kinesics was found for binomial 3 only (43\%). In the front position, percentages exceeded $50 \%$ in all binomials (minimum $=52.8 \%$ in binomial 3 ). For the back position, interaction was reduced in all binomials, as percentages ranged from 0\% (binomial 4) to $8.1 \%$ (binomial 5).

Distance: intimate distance showed high percentages in all binomials, ranging from 73.6 to $97.3 \%$ in binomials 3 and 5, respectively.
Visual contact: the category "child looks at mother" was little observed. The highest score for "mother looks at child" was found in binomial 1 (78.1\%). Eye-to-eye contact dominated in binomial 5's interactions.

Tone of voice (maternal): whispering predominated in binomial 5's interaction (60.8\%), while the normal/high tone of voice was constant in binomial 3 (45.8\%). Silence was found in $91.5 \%$ of binomial 1 's interactions.

Crying/moaning (baby): in $22.4 \%$ of binomial 4 's interactions, the baby cried or moaned. This situation, on the opposite, did not occur in binomial 2.

Touch/child: as for touching provoked by the child, also called "child's tactile behavior", only two variables were found - turns towards the mother and turns towards the side opposite to the mother. The first variable prevailed in binomial $5(81 \%)$. The second variable showed high levels in binomial 1 (36.6\%). The absence of the child's tactile behavior was also identified, mainly in binomial 1 (51.2\%).

Touching/mother: in touching provoked by the mother, called "maternal tactile behavior", localized touch levels ranged from 48.7 to $75.9 \%$. Strongly holding and caressing were also identified more frequently in 
binomial $5(36.5 \%)$ and $3(12.5 \%)$, respectively. Smiling was verified in $13.5 \%$ of interactions in binomial 5 .

\section{Discussion}

Children's babbling depends on adult stimulation and greater mutual interaction. As soon as the children can voice sounds, mothers respond to the children's vocalization by also producing some kind of sound. This stimulates the children ${ }^{(9)}$. Hence, over time, children will babble more if the mother figure is available. Children going to kindergarten, without the mother's presence, exhibit less babbling patterns than children created with the family(10). Thus, even when mothers are present in the home environment, given the importance of responding to babies' paralinguistic manifestations, it is fundamental to stimulate mothers to establish this kind of communication with their children.

Due to the children's age and with a view to maternal care, proximal distance is needed between both. A comparative communication study between HIV-positive and negative mothers ${ }^{(11)}$ showed that intimate distance was more frequent between HIV-positive mothers and children, probably due to the mothers' anguish during pregnancy because of the HIV and the appraisal of motherhood when their children are close to them.

In general, the occurrence of lateral or back position and personal distance can be related with the search for some material needed for care delivery. It should be analyzed, however, if mother/child communication was not met with disinterest in some cases.

As perceived in this research, in binomial 3, who assumed the lateral or back position towards her baby in almost half of her interactions, also presented the highest frequency of personal distance during interactions with her child. At the time of the recordings, the same mother showed considerable anxiety. When people are anxious, they frequently do not manage to pay sufficient attention to the other with a view to interacting. This can justify this mother's apparent distancing from her baby. She reported that she was met with prejudice in her work environment (a health unit) due to her HIV-positive condition. Moreover, she had recently returned to work and care for her baby was delegated to her 12-year-old daughter most of the time. The fact of being recorded, "assessed" by health professionals, may have produced fear of not showing skills for care delivery to the child. Hence, she was more concerned with technical, skillful care and deviated her attention from communication.

As for mother 5, who most frequently maintained intimate distance from her baby, she discovered her HIVpositive status during pregnancy. The mother may have bonded with her baby, as the child starts to represent life, challenging death due to an incurable disease.

Visual contact represents an important communication means between mother and child, especially during the first days of life ${ }^{(12)}$. Looking at the child means believing that he is healthy, without any apparent abnormalities, the certainty an HIV-positive mother seeks until the diagnosis of her child has been reached. After four weeks, the baby demonstrates preference for human faces and, at 14 weeks, prefers to look at the mother's face instead of any other face(6). However, low answer levels were identified for "child looks at mother" or "eye-to-eye contact". This fact may be due to the limitations of the recording, which did not permit a clear focus on the baby's look.

Voice is one of the communication instruments. It is not exclusive to verbal language, however. The tone imposed when speaking can reflect feelings and intentions, demonstrate intimacy between the interlocutors or not. It depends on the distance between the producer and receiver of the message and can be regulated to increase or decrease this distance ${ }^{(8)}$. The prevalence of intimate distance between the binomials explains the higher levels of whispering and low tone of voice in the observed recordings. Hence, the higher frequency of high/normal tone of voice is also justified by the mother's position and distance from her child.

In general, crying and moaning are related to feelings of discomfort, dissatisfaction or pain. This sign by children makes anyone who hears it want to try and finish it. Tactile, vocal and proprioceptive stimuli can make babies stop crying when they are not cold, hungry or hot ${ }^{(6)}$. Child 2 was the oldest baby, was curious about the environment and did not seem to pay attention to any stimulus that could lead to crying or any displeasure. Baby 4, on the other hand, was the youngest child and was probably surprised by the recording site.

As for the children's tactile behavior, they may have turned to one side or another due to the mother's handling, the desire to reach an object that attracted their attention, or to actually get closer to or more distant from the mother's company. The meaning of movement, as a component of kinesics, depends on the context it occurred in ${ }^{(13)}$.

About the mother's tactile behavior, the most used type was localized touching, which is useful to call someone's attention or when performing some procedure or care, as the mothers were requested to during the 
recordings. When performing some procedure, whoever is touching not always wants to communicate something, but whoever is touched can always have different, positive or negative feelings. Everything will depend on the context the situation occurs in.

Massaged infants fell asleep or presented alert but calm behavior during the massage(14). In this research, caressing may have been one way mothers used to calm down the baby. One mother used "strongly holding" more than others, representing the desire to keep the baby close to her at all times and a form of protection.

Smiling is a universal manifestation of joy or satisfaction. For the mothers, it represents the certainty that their baby is fine, despite their HIV-positive condition during the pregnancy.

\section{Conclusions}

The research complied with the goals, despite the limitations of earlier research on the theme, which are necessary to oppose the results. It contributed by indicating important aspects in the development of affective mother/child bonding, including effective communication.

\section{References}

1. Canavarro MC. Gravidez e maternidade: representações e tarefas de desenvolvimento. In: Canavarro MC. Psicologia da gravidez e da maternidade. Coimbra: Quarteto Editora; 2001. p. 17-49.

2. Campos AC. O significado de ser mãe de um recém-nascido sob fototerapia: uma abordagem humanística. [dissertação]. Fortaleza (CE): Departamento de Enfermagem/UFC; 2003.

3. Cabrita A, Carneiro A, Menaia MA experiência psicológica da gravidez na mulher soropositiva para o HIV. Lisboa [on line] 2003 set; [citado 2007 março 12]; 40 Congresso Virtual HIV/ Aids. [12 telas]. Disponível em: http://www.aidscongress.net/ pdf.177.pdf

4. Moura EL, Praça NS. Transmissão vertical do HIV: expectativas e ações da gestante soropositiva. Rev Latino-am Enfermagem 2006; 14(3):405-13.

5. Rocha SMM, Simpionato E, Mello DF. Apego mãe-filho: estudo comparativo entre mães de parto normal e cesárea. Rev Bras Enferm 2003; 56(2):125-9.

6. Bowbly J. Apego. São Paulo (SP): Martins Fontes; 1990.

7. Silva MJP. A comunicação tem remédio: a comunicação nas relações interpessoais em saúde. São Paulo (SP): Loyola; 2003.
In general, HIV-positive mothers use NVC to interact with their children, whom they are intimately attached to, probably due to both the desire to have them, thus challenging the disease, and the guilt they feel because they generated a child in a risk situation. They also use NVC to assess their children and perceive abnormalities.

The recent discovery of HIV infection can tighten the mother's bond with her baby after birth. The child represents life. Threatened by an incurable disease early in life, maternal care is intensified, perhaps as a way of bargaining more time to live or due to the possibility of the child's infection, as maternal HIV represents a first loss: of dreams and projects. The child's infection would be a seond and possibly more painful loss.

The anxiety caused by assessment in an experimental environment probably led to the mothers' more technical care performance. Hence, a study of mothers in a natural situation could explain differences in maternal performance when compared with the present research.

A comparative research is suggested between HIVpositive and negative mothers, submitted to the same situation, so as to sustain the findings presented here.

8. Hall ET. A dimensão oculta. Lisboa: Relógio D’água; 1986.

9. Rubino R. Representando o interlocutor no período prélinguístico. [dissertação]. São Paulo (SP): Pontifícia Universidade Católica; 1989.

10. Lima MCMP, Barbarini GC, Gagliardo HGRG, Arnais MAO, Gonçalves VMG. Observações do desenvolvimento de linguagem e funções auditiva e visual em lactentes. Rev Saúde Pública 2004; 38(1):106-12.

11. Vasconcelos SG. Estudo comparativo da comunicação proxêmica entre mãe-filho portadores do HIV ou não em alojamento conjunto. [dissertação]. Fortaleza (CE): Departamento de Enfermagem/UFC; 2006.

12. Queiroz TCN. Entrando na linguagem. Estilos Clin 2003; 8(15):12-33.

13. Birdwhistell R. Kinetics and context: essays on body motions communication. Philadelphia: University of Pensylvania Press; 1985.

14. Fogaça MC, Carvalho WB, Peres CA, Lora MI, Hayashi LF, Verreschi ITN. Salivary cortisol as an indicator of the adrenocortical function in healthy infants with massage therapy. São Paulo Med J 2005; 123(5):215-8. 